

\section{Sillares}

Revista de Estudios Históricos

http://sillares.uanl.mx/

Hacer a Nuevo León un reino de nuevo. El proyecto nostálgico de Abelardo A. Leal y la excepcionalidad regiomontana

\section{Make Nuevo León a kingdom again. Abelardo A. Leal's nostalgic project and the exceptionality of Monterrey}

Aarón B. López Feldman

Instituto Tecnológico y de Estudios Superiores de Occidente orcid.org/0000-0002-0395-7815

Recibido: 21 de agosto de 2021 Aceptado: 1 de octubre de 2021 Publicado: 1 de enero de 2022

Copyright: (C) 2022, Aarón B. López Feldman. This is an openac-cess article distributed under the terms of Creative Commons At-tribution License [CC BY 4.0], which permits unrestricted use, distribution, and reproduction in any medium, provided the orig-inal author and source are credited.

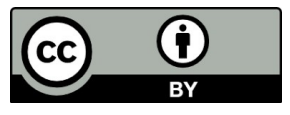

DOI: https://doi.org/10.29105/sillares1.2-1 


\title{
Hacer a Nuevo León un reino de nuevo. El proyecto nostálgico de Abelardo A. Leal y la excepcionalidad regiomontana
}

\begin{abstract}
Make Nuevo León a kingdom again. Abelardo A. Leal's nostalgic project and the exceptionality of Monterrey
\end{abstract}

\author{
Aarón B. López Feldman \\ Instituto Tecnológico y de Estudios Superiores de Occidente \\ orcid.org/0000-0002-0395-7815
}

Resumen: En este ensayo se analiza el proyecto nostálgico de Abelardo A. Leal Leal Sr. (1899-1982), escritor y abogado autodidacta regiomontano, padre de Abelardo A. Leal. Jr. (1922-1994), quien fuera editor, subdirector y presidente de El Norte durante más de tres décadas. En El Nuevo Reyno de León: un Estado sin impuestos (1975), texto que articula su proyecto nostálgico, Abelardo Leal Sr. propone demandar, ante la Corte Internacional de Justicia y la Organización de las Naciones Unidas, que a Nuevo León se le restituya el territorio mercedado a Luis Carvajal y de la Cueva en 1579 bajo el rubro del "Nuevo Reyno de León", una demanda que haría que Nuevo León se hiciera con una parte importante del norte de México e, incluso, de Texas. Lejos de abordarlo como una curiosidad histórica, un absurdo o una excentricidad, propongo ubicar dicho proyecto (escrito a mitad de la década de los setenta del siglo XX, en pleno enfrentamiento entre la elite empresarial local y el Estado mexicano) como parte de las narrativas de la excepcionalidad regiomontana, un denso tejido de afirmaciones identitarias según las cuales Monterrey es una singularidad en la historia nacional, una particularidad primigenia y esencializada, cuyo "éxito" y "grandeza"

Sillares, vol. 1, núm. 2, 2022

16

DOI: https://doi.org/10.29105/sillares1.2-1 
se formaron a espaldas, a pesar y en contra del centro. Leído desde esta perspectiva sociohistórica, el proyecto de Leal comparte relaciones de sentido con afirmaciones que, hoy en día, son frecuentes en la vida política neoleonesa y en las redes sociodigitales, ya sea bajo la forma de amenazas de sacar a la entidad del pacto fiscal o bien de propuestas radicales de separar a Nuevo León del resto de la nación. Desde esta perspectiva, el proyecto nostálgico de Abelardo Leal nos permite ahondar en las grietas del Estado-nación mexicano en tanto unidad comunitaria imaginada y configuración sociohistórica de alteridades.

Palabras clave: Abelardo A. Leal; Nuevo Reino de León; Nuevo León; Monterrey; excepcionalidad regiomontana.

Abstract: This essay analyzes the nostalgic project of Abelardo A. Leal Leal Sr. (1899-1982), a writer and self-taught lawyer from Monterrey, father of Abelardo A. Leal. Jr. (1922-1994), who was editor, vice principal and president of El Norte for more than three decades. In El Nuevo Reyno de León: un Estado sin impuestos (1975), a text that articulates his nostalgic project, Abelardo Leal Sr. proposes to demand, before the International Court of Justice and the United Nations, that Nuevo León be restored the territory granted to Luis Carvajal y de la Cueva in 1579 under the heading of "Nuevo Reyno de León", a demand that would make Nuevo León take over an important part of northern Mexico and even Texas. Far from approaching it as a historical curiosity, an absurdity or an eccentricity, I propose to place this project (written in the mid-1970s, amid the confrontation between local business elite and Mexican State) as part of the Monterrey's exceptionality narratives, an identity afirmations dense weave according to which Monterrey is a singularity in national history, a primal and essentialized particularity, whose "success" and "greatness" were formed behind the back, despite and against the center.

Keywords: Abelardo A. Leal; Nuevo Reino de León; Nuevo León; Monterrey; Regionalism. 
En septiembre de 1996 Luis Enrique Grajeda, director del Centro Patronal de Nuevo León (CPNL), propuso que en esta entidad se organizara una consulta, como la de 1995 en Quebec, a través de la cual los nuevoleoneses pudieran decidir si querían seguir siendo parte de la federación o si preferían independizarse: "No es justo que produzcamos lo que produce per cápita Suiza y vivamos como están viviendo en Oaxaca... Estamos hartos de todo ya. Trabaje y trabaje para mantener el ocio en toda la República Mexicana, principalmente en el Distrito Federal. Y todo corrupto además". ${ }^{1}$ A los pocos días, El Norte (que había recogido la declaración del director del CPNL) publicó un artículo de opinión en el cual se hacía eco de la propuesta de Grajeda y se enaltecía su "brevísimo valor civil" de sugerir la consulta en Nuevo León "para decidir si queremos continuar siendo parte de una Federación Mexicana, mangoneada por el grupo de Zedillo, que nos tiene hundidos... como que se antoja preguntar: ¿Pues qué ganamos con que nuestra Patria Chica sea parte de una República toda leprosa?", y remataba: "Los inútiles y estériles patrioterismos necios no ayudarán en nada a resolver esta cuestión. La historia, la realidad y la inteligencia deben nutrir el debate de si Nuevo León debe o no seguir siendo parte de la Federación Mexicana".2

Periódico El Norte, "Recomienda CPNL consulta tipo Quebec". Monterrey, N.L., 7 de septiembre de 1996.

2 Periódico El Norte, “Independizar a Nuevo León?”. Monterrey, N.L., 9 de septiembre de 1996.

Sillares, vol. 1, núm. 2, 2022

DOI: https://doi.org/10.29105/sillares1.2-1 
Dos meses después, en las mismas páginas de El Norte, el historiador Héctor Jaime Treviño Villareal, hacía alusión a los duros ataques que había recibido el director del Consejo Patronal de Nuevo León por atentar contra la unidad de la patria y recordaba que, lejos de ser una ocurrencia individual, la propuesta de Grajeda formaba parte de "un pensamiento muy constante desde hace tiempo en algunos cerebros regiomontanos". ${ }^{3} \mathrm{Y}$ en la misma línea de ese pensamiento, el historiador situaba el surgimiento de un grupo separatista en Internet (alojado en el ahora extinto GeoCities): la República Separatista de Nuevo León. Tras un breve repaso histórico por las encarnaciones del fantasma del separatismo en el noreste, Treviño Villareal sostenía: "La aparición de estas ideas o rumores en los últimos días, aunque aparentemente no pasa de ser una 'vacilada', nos mueve a meditar sobre su origen", ${ }^{4}$ y agregaba: "no es difícil encontrarlo: el centralismo atroz y el localismo exacerbado por ciertos sectores, diciéndonos que somos los mejores y los más buenos y que los compatriotas del centro y sur del País viven gracias a nuestro trabajo". El artículo pedía, por último, "estar al pendiente

3 Periódico El Norte, “¿República de Nuevo León?”. Monterrey, N.L., 23 de noviembre de 1996.

4 Una semana antes del artículo de Treviño Villareal, El Norte había dado a conocer el surgimiento de la República Separatista (Periódico El Norte, "Nuevo León: ¿nuevo país?”. Monterrey, N.L., 15 de noviembre de 1996). Y al día siguiente de publicada dicha nota, el gobernador interino Benjamín Clariond Reyes declaró: "Ha de ser una vacilada de alguien que no tiene nada qué hacer, que se ponga a ver la tele mejor" (Periódico El Norte, "Califican de "vacilada" propuesta separatista". Monterrey, N.L., 16 de noviembre de 1996).

Sillares, vol. 1, núm. 2, 2022

DOI: https://doi.org/10.29105/sillares1.2-1 
de las manifestaciones políticas de la juventud mexicana que ya no fue educada en el nacionalismo revolucionario" y comparaba la existencia de este grupo separatista digital con los rumores de agrupaciones de jóvenes neonazis en colonias de alto estrato socioeconómico del área metropolitana de Monterrey.

El artículo de Treviño Villareal no sólo ponía sobre la mesa la pugna sociohistórica entre dos producciones discursivas (el "centralismo atroz" y el "localismo exacerbado"), sino que también relacionaba, como parte de dicha pugna, la amenaza separatista del líder patronal con el surgimiento de la República Separatista de Nuevo León. En lugar de tomar a este grupo sociodigital como una simple "vacilada" (práctica reduccionista muy común tanto en esos tiempos como ahora), Treviño Villareal identificaba relaciones históricas de sentido entre dicho grupo y la propuesta de Grajeda.

Dos décadas después, con la explosión de las redes sociodigitales, de la co-presencia mediada electrónicamente y del nuevo espacio-tiempo de sus interacciones, ${ }^{5}$ se han potenciado las capacidades para conectar los malestares y los afectos regionalistas/separatistas, y han surgido otros espacios similares a la República Separatista de Nuevo León. Así, entre 1996 y el 2019, se crearon más de 40 grupos y páginas, tan sólo en Facebook, que promueven la separación de Nuevo León o del noreste de México

$5 \quad$ Manuel Castells, Comunicación y poder (Madrid: Alianza, 2009); Henry Jenkins, Convergence Culture. La cultura de la convergencia de los medios de comunicación (Barcelona: Paidós, 2008).

Sillares, vol. 1, núm. 2, 2022

DOI: https://doi.org/10.29105/sillares1.2-1 
como un todo. ${ }^{6}$ Con el tiempo, algunos de esos espacios digitales han desaparecido (porque sus creadores los cerraron o porque Facebook los dio de baja ante denuncias de incitación al odio), pero la mayoría continúa vigente. Más allá del tiempo de vida de cada uno de esos espacios, lo significativo es que en todos ellos se mantienen los mismos referentes y temas aglutinantes, los cuales están enraizados en los imaginarios sociohistóricos locales (Santiago Vidaurri, las supuestas República del Río Grande ${ }^{7}$ y de la Sierra Madre, el espíritu de lucha contra el medio agreste, el centralismo y la injusticia fiscal con el norte...). En este sentido, lo importante de estos espacios sociodigitales no es su inmanencia, su número de practicantes o su (im)posibilidad para llevar a

6 Según Villasana Dávila (Regionalismo politico en México en el periodo 2000-2007: ¿un fenómeno que resurge? Tesis Doctoral. Universidad del País Vasco, http://xurl.es/d03m4), entre 1996 y 2009 existieron, al menos, 12 grupos o páginas en internet que promovían explícitamente la separación de todos o algunos estados del norte de México. En mi tesis doctoral (López Feldman, Aarón, Re-sentimientos de la nación. Regionalismos, separatismos e imaginación política en narrativas de la excepcionalidad regiomontana), registré la existencia, del 2010 al 2019, de 35 grupos y páginas, entre los cuales podemos destacar los siguientes: "Yo también creo que el norte de México debería ser independiente"; "Viva La Republica Del Rio Grande"; "ProAridoamérica"; "Aridoamérica independiente"; "Movimiento Nacionalista Riograndense"; "República de Nuevo León"; "República de México del Norte"; "República Norestense"; "Orgullo NeoLeonés"; "Historia Neoleonesa"; "Por una Aridoamérica independiente"; "Nación Neoleonesa"; "Identidad neoleonesa"; "Por una Autentica Soberanía y Autonomía de Nuevo León"; "Rugido de León / Podcast"; "Patria NeoLeonesa"; "Rancheros Locos de Río Grande".

7 Josefina Zoraida Vázquez, "La supuesta República del Río Grande", en Décadas de inestabilidad y amenazas. Antología de ensayos, ed. Josefina Zoraida Vázquez (El Colegio de México, 2010), 61-88.

Sillares, vol. 1, núm. 2, 2022

DOI: https://doi.org/10.29105/sillares1.2-1 
cabo sus anhelos de separación, lo importante es lo que los une con las demandas políticas centrales, es decir, con la formación histórica de la alteridad regiomontana en sus relaciones de tensión, complementariedad y oposición con el centralismo mexicano. En otras palabras, lo relevante no es si los grupos y páginas separatistas pueden o no existir "fuera de Facebook" según los criterios de realidad y de existencia de la política clásica (menos aún, si deban o no hacerlo), sino que miles de personas los están imaginando (entre el juego y el anhelo, entre lo digital y lo físico, entre lo viejo y lo nuevo), conversando y promoviendo, y que lo hacen no desde un espacio vacío, absurdo, sino desde un denso tejido histórico-cultural de referentes compartidos que expresan muchas de las tensiones socio-espaciales vinculadas con la construcción histórica del eje regional Monterrey-Nuevo León-Noreste en tanto frontera económica, política y civilizatoria.

En este ensayo mostraré parte de ese tejido históricocultural a través de lo que llamo las "narrativas de excepcionalidad regiomontana", las cuales, en tanto conjunto de afirmaciones identitarias que circulan en medios impresos y en grupos de replicación digital, dan cuenta de dos orgullos socio-espaciales en constante tensión: el orgullo centralista del altiplano (vinculado con la voluntad de una parte hegemónica que se propone a sí misma como centro y, a la par, como unidad del todo nacional), y el orgullo regionalista de la alteridad regiomontana (vinculado con la voluntad de una parte regional que se propone a sí misma como Sillares, vol. 1, núm. 2, 2022 
una particularidad radical y esencial, una excepcionalidad de la historia nacional). En otro lado me he ocupado de un conjunto amplio de esas narrativas de excepcionalidad y de sus condiciones de producción y circulación, ${ }^{8}$ aquí me enfocaré exclusivamente en un texto concreto de dicho conjunto: El Nuevo Reyno de León. Un Estado sin impuestos, de Abelardo A. Leal Sr. ${ }^{9}$ Al final de este ensayo, trazaré algunas de las relaciones sociohistóricas de sentido entre dicho texto y los espacios separatistas de Facebook.

\section{Narrativas de excepcionalidad en la alteridad regiomontana}

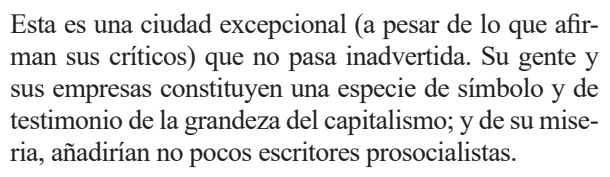

Federico Arreola, ¿Por qué Monterrey?

La nación no sólo es una comunidad política imaginada, basada en la construcción de horizontalidad, ${ }^{10}$ sino también una configuración cultural, ${ }^{11}$ una formación histórica de alteridad y de diver-

\footnotetext{
8 Aarón López Feldman, "Re-sentimientos de la nación. Regionalismos, separatismos e imaginación política en narrativas de la excepcionalidad regiomontana" (Instituto Tecnológico y de Estudios Superiores de Occidente, 2019).

9 Abelardo Leal, El Nuevo Reyno de León. Un Estado sin impuestos (Monterrey: Universidad Autónoma de Nuevo León, 1982).

10 Benedict Anderson, Comunidades imaginadas. Reflexiones sobre el origen y la difusión del nacionalismo (México, DF: Fondo de Cultura Económica, 1993).

11 Alejandro Grimson, Los límites de la cultura. Críticas de las teorías de la identidad (Buenos Aires: Siglo XXI, 2011), 171-94.
}

Sillares, vol. 1, núm. 2, 2022

DOI: https://doi.org/10.29105/sillares1.2-1 
sidades ${ }^{12}$ que produce diferencias constitutivas, esto es, múltiples otredades y fronteras, tanto internas como externas. Por ende, las afirmaciones regionalistas y separatistas no responden únicamente a las distintas crisis de lo estatal y de lo nacional (sin duda, fundamentales), sino que forman parte intrínseca del ejercicio del Estado-nación como proyecto histórico y de su devenir como narrativa sociocultural (es decir, como un todo representado a través de una de sus partes). En palabras de Renato Ortiz: "La identidad nacional se construye en detrimento de las identidades locales. Ella se nutre de su neutralización o de su destrucción. La constitución de la nación es siempre conflictiva. Al afirmarse la unidad del todo, se niega la particularidad de las formaciones específicas". 13

En este sentido, el Estado-nación es un proyecto necesariamente inconcluso que pretende hacer de sí un todo homogéneo (mayor que la suma de sus partes) a través de una serie de artefactos político-simbólicos: la escuela y sus libros (en tanto síntesis de la historia oficial), el museo y su memoria selectiva, el censo y sus clasificaciones legítimas, el mapa y su

12 Claudia Briones, "Formación de alteridad, contextos globales, procesos nacionales y provinciales", en Cartografias argentinas. Políticas indigenistas y formaciones provinciales de alteridad (Buenos Aires: Antropofagia, 2005), 10-39; Rita Laura Segato, "Identidades políticas y alteridades históricas: una crítica a las certezas del pluralismo global”, Nueva Sociedad, núm. 178 (2002): 104-25.

13 Renato Ortiz, Otro territorio. Ensayos sobre el mundo contemporáneo (Bogotá: Convenio Andrés Bello, 1998), 125.

Sillares, vol. 1, núm. 2, 2022

DOI: https://doi.org/10.29105/sillares1.2-1 
logoización del territorio, la constitución y su ciudadanía. ${ }^{14}$ Las partes del todo nacional, sin embargo, nunca quedan plenamente totalizadas, y es sólo cuestión de tiempo para que algunas de ellas se desplacen de la tensión al conflicto. Por eso, con frecuencia, el proyecto nacional busca neutralizar y utilizar a su favor las afirmaciones identitarias locales y regionales, así como erradicar las aspiraciones de aquellas partes que no se asumen como dependientes del todo unitario.

En el caso del Estado-nación mexicano, la construcción del centro de México como totalidad nacional, es decir, la construcción de la Ciudad de México, el altiplano y su área de influencia directa como núcleo de acción político-económica y encarnación simbólica de la nación, ha sido un proceso largo y disputado que hunde sus raíces en la difícil transición entre el Estado colonial y el Estado-nación, así como en las herencias espaciales de larga duración que dejó la geografía mexica. ${ }^{15} \mathrm{~A}$

14 Anderson, Comunidades imaginadas. Reflexiones sobre el origen y la difusión del nacionalismo; Santiago Castro-Gómez, "Ciencias sociales, violencia epistémica y el problema de la invención del otro", en La colonialidad del saber. Eurocentrismo y ciencias sociales. Perspectivas lationoamericanas (Bogota: Consejo Latinoamericano de Ciencias Sociales, 2000), 88-98; Ortiz, Otro territorio. Ensayos sobre el mundo contemporáneo.

15 Bernardo García Martínez, "El espacio del (des)encuentro", en Encuentro en la frontera: mexicanos y norteamericanos en un espacio común (México, DF: El Colegio de México - Centro de Estudios Históricos; El Colegio de la Frontera Norte; Universidad Autónoma de Tamaulipas, 2001), 19-51. Bernardo García Martínez, El desarrollo regional, siglos XVI al XX (México, DF: El Colegio de México, 2004); Bernardo García Martínez, Las regiones de México. Breviario geográfico e histórico (México, DF: El Colegio de México, 2008).

Sillares, vol. 1, núm. 2, 2022

DOI: https://doi.org/10.29105/sillares1.2-1 
pesar de lo que sostiene su historia mítica, el centro se construyó a la par del resto de las regiones, pero con la capacidad de absorber los efectos de su propia centralización. En este sentido, el norte, como frontera interna, jugó un papel clave en la formación nuclear del centro. El norte no nació vacío, aislado, lejano; su lejanía, su aislamiento y su vacuidad se construyeron en su particular relación histórica con el centro. ${ }^{16}$

Desde la perspectiva de las fijaciones de sentido que hicieron nación (en tanto relato sociocultural y proyecto histórico), lo que no es centro es vacío, lejanía, periferia, tradición, provincia, interior, región, pero también caos, peligro, barbarie, precariedad, atraso, conservadurismo, ignorancia, minoría de edad, superstición. A esas fijaciones semánticas del "ellos" y el "afuera" como fronteras culturales internas, se le contrapone el "nosotros" y el "adentro" de la nación: orden, modernidad, ilustración, razón, civilización, progreso, educación, ciencia, conjunto, cuna, revolución. ${ }^{17}$

16 Israel Cavazos Garza y César Morado Macías, "Introducción", en Fábrica de la frontera. Monterrey, capital de Nuevo León (1596-2006) (Monterrey: Ayuntamiento de Monterrey, 2006), 17-20; Cecilia Sheridan Prieto, Fronterización del espacio hacia el norte de la Nueva España (México, DF: Centro de Investigaciones y Estudios Superiores en Antropología Social; Instituto Mora, 2015).

17 Luis Aboites Aguilar, "En busca del centro. Una aproximación a la relación centro-provincia en México, 1921-1949”, Historia Mexicana 59 (2009): 71154. Manuel Ceballos Ramírez, "Visiones contradictorias del norte mexicano: elementos de una historia cultural", en Historia, región y frontera norte de México (México, DF: Bonilla Artigas; Universidad Autónoma de Tamaulipas, 2011), 193-220. Periódico El Universal, Monsiváis, Carlos (2009). ¿Qué se Sillares, vol. 1, núm. 2, 2022 
Aesas fijaciones de sentido centralistas se les ha contestado, en modos y tiempos distintos, desde otras regiones del país fuera de la región central. Desde el eje Monterrey / Nuevo León / Noreste, una respuesta llegó acompañada de las potencialidades (es decir, de la capacidad de hacer escuchar sus inconformidades y de poner sobre la mesa nacional no sólo su peso específico como parte, sino también su virtualidad como todo aparte) de una elite construida en torno al desarrollo comercial, industrial y financiero. ${ }^{18}$ Desde la alteridad regiomontana, se produjo un tejido de afirmaciones identitarias socio-espaciales que, a modo de narrativas de excepcionalidad, responde a la centralización $\mathrm{y}$ totalización del centro. Esas narrativas proponen otro tipo de mestizo y otro tipo de relaciones económico-políticas como simientes de su alteridad y, en ocasiones, de lo que deberían ser las "auténticas" fijaciones de la mexicanidad.

fizo de la provincia?, 26 de abril de 2009. Acceso el 17 de febrero de 2018 http://archivo.eluniversal.com.mx/editoriales/43850.html; Enrique Raichenberg y Catherine Héau-Lambert, "La frontera en la comunidad imaginada del siglo XIX”, Frontera Norte 19, núm. 38 (s/f): 37-61; Sheridan Prieto, Fronterización del espacio hacia el norte de la Nueva España; José Manuel Valenzuela Arce, "Interculturalidad y estados nacionales", en Pensar las ciencias sociales hoy. Reflexiones desde la cultura, ed. Rossana Reguillo y Raúl Fuentes Navarro (Guadalajara: Instituto Tecnológico y de Estudios Superiores de Occidente, 1999), 119-42.

18 Mario Cerutti, Burguesía y capitalismo en Monterrey (1850-1910) (México, DF: Claves Latinoamericanas, 1983); Mario Cerutti, Burguesía, capitales e industria en el norte de México. Monterrey y su ámbito regional (1850-1910) (Monterrey: Universidad Autónoma de Nuevo León; Alianza, 1992); Menno Vellinga, Desigualdad, poder y cambio social en Monterrey (México, DF: Siglo XXI, 1988).

Sillares, vol. 1, núm. 2, 2022

DOI: https://doi.org/10.29105/sillares1.2-1 
Podemos entender a las narrativas de la excepcionalidad regiomontana como un denso tejido de afirmaciones identitarias socio-espaciales según las cuales Monterrey (y cuando se dice Monterrey se habla de Nuevo León y del noreste todo ${ }^{19}$ ) es una singularidad en la historia nacional, una particularidad primigenia y esencializada que, formada a espaldas, a pesar y en contra del centro $^{20}$ (y cuando se dice el centro se habla de la Ciudad de México como núcleo del Estado novohispano y del Estado-nación), se caracteriza por su "cultura de trabajo" traducida en potencial económico (comercial, industrial y financiero), educativo (con el Tecnológico de Monterrey como núcleo ${ }^{21}$ ) y cultural (tanto en términos de $\operatorname{arte}^{22}$ y conocimiento, como de ethos empresarial

19 "Todos los nacidos en el Estado somos neoleoneses y todos los neoleoneses somos regiomontanos", diría José P. Saldaña (Grandeza de Monterrey y estampas antiguas de la ciudad. México: Empresas Editoriales S.A, 1973), p. 65.

20 El centro / sur "huevón, ocioso y corrupto" que vive a costa del Monterrey "trabajador, madrugador y franco".

21 Además del Tecnológico de Monterrey y del conglomerado empresarial comúnmente asociado con la ciudad, existe otro caso de "éxito regio" que "conquistó" el centro del país: el periódico El Norte del que derivó el Grupo Reforma: "(El Norte) Fue un éxito rotundo en términos de circulación ya que contó con la capacidad de transferir los aspectos más liberales de la visión emprendedora regiomontana al contexto específico de la Ciudad de México. En el ámbito político, el periódico Reforma se presentó con una postura crítica hacia políticas oficiales y, en el ámbito económico, se caracterizó por la promoción de un modelo que favorecía la libertad de mercado" Smith Pussetto, C., García Vázquez, N. J., Pérez Esparza, J. D. (Análisis de la ideología empresarial regiomontana. Un acercamiento a partir del periódico El Norte, en CONfines de Relaciones Internacionales y Ciencia Politica, 2008). Disponible en http://www.redalyc. org/html/633/63340701//, Consultado el 10 de mayo de 2018, p. 17.

22 Como señala Eduardo Ramírez (El triunfo de la cultura. Uso político y Sillares, vol. 1, núm. 2, 2022 
distinguido por el trabajo, la honradez, el ahorro, el tesón y la innovación ${ }^{23}$ ). Según estas narrativas, el potencial de la parte regia se forjó en la lejanía, en la lucha con el medio agreste, con los indígenas seminómadas y con los invasores extranjeros, y en la mezcla sui géneris de grupos étnicos.

Estas narrativas de excepcionalidad son enunciadas por distintos actores en múltiples espacios discursivos, ${ }^{24}$ pero su densidad no se reduce ni a su textualidad ni a su lugar concreto

económico de la cultura en Monterrey. Monterrey: Fondo Editorial de Nuevo León, 2009), el arte, y su trabajo museístico, no sólo ha sido un elemento fundamental en la construcción identitaria del "orgullo regio", sino también en el despliegue de las tensiones sociohistóricas entre la elite empresarial regiomontana y el Estado mexicano.

23 En años recientes, los dos equipos de futbol locales (Tigres y Rayados de Monterrey) han comenzado a jugar un papel similar en estas narrativas de excepcionalidad. En la retórica que acompaña las finales de liga del futbol mexicano protagonizadas por estos dos equipos, no sólo se habla de su desempeño futbolístico, sino también del particular modelo de negocios que lo permite y de la necesidad de emularlo en todo el país; o bien, se afirma que es un ejemplo más de la "grandeza regia". En este contexto, un comentarista local [N. del E.: el autor se refiere Mario Castillejos] afirmó: "La grandeza de Monterrey, del industrial de Monterrey, de la sociedad de Monterrey, simplemente faltaba que también coronara en el futbol, hoy coronaron, desde hace tiempo ya vienen coronando, y hoy es el ombligo del futbol del país, y no es porque yo sea quien viva aquí, es porque geográficamente a mí me toca llevar una crónica que ni los chilanguitos ni los jalisquillos ni los del Pacífico te pueden llevar la cuenta de cuántas finales se pueden jugar en un lugar y cuántas se van a ganar. Bendito Dios esta ciudad ya levantó la mano y ahora para que nos la bajen se la van a pelar un rato" (Publicado en YouTube: https://www.youtube.com/ watch? $\mathrm{v}=-\mathrm{bQ} 7 \mathrm{vydcMo \& ab}$ channel=CharlsCepeda, 16 de agosto de 2019). 24 López Feldman, "Re-sentimientos de la nación. Regionalismos, separatismos e imaginación política en narrativas de la excepcionalidad regiomontana", 55-93.

Sillares, vol. 1, núm. 2, 2022

DOI: https://doi.org/10.29105/sillares1.2-1 
de enunciación, sino que forma parte de un proceso de larga duración surgido con la conformación histórica de la alteridad regiomontana en tanto uno de los otros internos clave del imaginario nacionalista mexicano (no el otro indígena con base en el cual se creó el mestizo de la nación, sino el mestizo fronterizo, "inculto", "primario", "bárbaro"). Por un lado, esta formación de alteridad lleva la huella de la construcción del centro como todo hegemónico a través de una de sus partes (la Ciudad de México) y la construcción de sus otros internos, no sólo en términos de raza, sino también de cultura y de ubicación en la geografía de la nación; por el otro, dicha formación está anclada en las tensiones económicas, políticas y simbólicas (por recursos, territorios, decisiones y representación en el relato de lo nacional) que las elites locales han mantenido con el Estado mexicano desde fines del siglo XIX. ${ }^{25}$

Las narrativas de excepcionalidad son afirmaciones apologéticas, reivindicatorias y nostálgicas que aluden al éxito, la épica, la grandeza de Monterrey, Nuevo León y el Noreste (en ese orden) y que se nutren de la (re)apropiación histórica y la gestión de la memoria local. ${ }^{26}$ Aunque en este ensayo me enfoco en una

25 Michael Snodgrass, Deferencia y desafio en Monterrey. Trabajadores, paternalismo y revolución en México, 1890-1950 (Monterrey: Fondo Editorial Nuevo León, 2008); Alex Saragoza, La elite regiomontana y el Estado mexicano, 1880-1940 (Monterrey: Fondo Editorial Nuevo León, 2008).

26 García Alonso (2014) entiende a los "gestores de memoria colectiva" como aquellas "instituciones, grupos o individuos cuya interpretación de los hechos ocurridos es considerada como referente para una comunidad. Tan gestoras Sillares, vol. 1, núm. 2, 2022 
de esas narrativas unitarias y en sus relaciones de sentido con espacios sociodigitales, esto no quiere decir que las asuma como las únicas afirmaciones identitarias de la alteridad regiomontana. No estoy proponiendo que todos los regios se adscriben a las narrativas de excepcionalidad. De hecho, muchos las disputan desde la academia, ${ }^{27}$ el trabajo, las artes o el espacio público.

son las llamadas instituciones de memoria -normalmente organizaciones o fundaciones encargadas de la custodia material de los fondos documentales y la investigación que pueda ser relevante para comprender una época, un autor o un suceso determinado-, como las universidades - encargadas de generar versiones de la historia de las naciones, que luego es vulgarizada y transmitida a través de los manuales escolares hasta constituir un sustrato interpretativo que comparten cohortes generacionales-; los ancianos que conocen con detalle las genealogías y son los depositarios de los relatos y los saberes que constituyen el patrimonio de las familias; los especialistas rituales - con sus conocimientos esotéricos sobre las relaciones entre el mundo sobrenatural y el de la vida cotidiana-; las autoridades políticas - que normativizan la vida cotidiana para generar un orden basado en códigos morales que indican en cada momento lo que es correcto e incorrecto-, etcétera". Ver María García Alonso, "Los territorios de los otros: memoria y heterotopía", Cuicuilco 21, núm. 61 (2014): 334.

27 Existe una larga tradición de académicos e investigadores (Cecilia Sheridan, Lylia Palacios, Mario Cerutti, Máximo de León Garza, César Morado, Alex Saragoza, Michael Snodgrass, Alberto Barrera-Enderle, Octavio Herrera, por mencionar algunos) que, directa o indirectamente, han realizado una crítica económica, política e histórica a las narrativas de excepcionalidad. Desde esta perspectiva, el relato de la diferencia regia, de su particularidad, sólo puede ser entendido como parte de la formación histórica de una elite local que, basándose en su desarrollo comercial, industrial y financiero, fue capaz de imponer en el espacio regional la narrativa de su ethos empresarial. Desde la crítica a la excepcionalidad, Monterrey no es la gran ciudad industrial hecha por el mestizo fronterizo bajo la figura del hombre empresarial y del patriarca industrial, sino una urbe asimétrica, desigual, que "no puede explicarse sin la historia de sus fábricas y sus trabajadores, hombres y mujeres, ni de sus Sillares, vol. 1, núm. 2, 2022

DOI: https://doi.org/10.29105/sillares1.2-1 
Y así como no todos los regios se adscriben a estas narrativas, tampoco todos los que se adscriben a ellas son regios. Al respecto, José P. Saldaña (1891-1992, político, asesor empresarial, escritor, historiador y cronista oficial de Monterrey durante veinticinco años) afirma, apoyándose en el determinismo geográfico, que la "grandeza" del ethos regiomontano es una cualidad adquirible vía el contacto con el medio ${ }^{28}$ :

Queda en pie, con la limpieza que corresponde a las cosas respetables, el título de regiomontano. No debe tomarse, ni la tomamos como blasón de alcurnia, ni como distintivo de sangre limpia a lo Hitler. Nada de eso, aceptamos con satisfacción la formación del carácter regiomontano como producto del medio ambiente, sin que en ello cuente en forma alguna la cuna o el lugar en que se haya nacido. ${ }^{29}$

incontables talleres de oficios urbanos. Ellos y ellas fueron los constructores de esta ciudad, no la élite de unos cuantos 'indómitos e industriosos' empresarios" Lylia Palacios (2017). La Muerte obrera en Monterrey, en Académicxs de Monterrey, 43. https://academicxsmty43.blog/2017/11/20/la-muerte-obrera-en-monterrey-lylia-palacios/

28 En un tono similar, Santiago Roel (1885-1957), otro actor clave en la gestión de la memoria local y en la promoción cívica (creador, junto con Saldaña, del escudo de Nuevo León), señala en sus Apuntes Históricos: "Siempre que en estos Apuntes se hable de nuevoleoneses, entiéndase que no sólo he querido referirme a los nativos del Estado, sino también a todos aquellos que, sin serlo, se han avecindado aquí y sienten por Nuevo León igual o mayor afecto que por su lugar de origen; han formado un hogar o labrado un porvenir, y han contribuido con su sincero esfuerzo al progreso y bienestar de esta tierra". Ver Santiago Roel, Nuevo León, apuntes históricos (Monterrey: Ediciones Castillo, 1977), XIII.

29 José Pedro Saldaña, Grandeza de Monterrey y estampas antiguas de la ciudad (México, DF: Empresas Editoriales S.A., 1973), 257.

Sillares, vol. 1, núm. 2, 2022

DOI: https://doi.org/10.29105/sillares1.2-1 
Así, a la par del despliegue de sus potencialidades económicas y políticas, la alteridad regiomontana ha producido, desde fines de la década de los treinta del siglo $\mathrm{XX}^{30}$ (aunque con importantes antecedentes en la segunda mitad del siglo XIX y el periodo vidaurrista) una serie de narrativas de sí que tienden a esencializar

30 De la mano del centralismo político, económico y simbólico, se ha ejercido en el país una suerte de "centralismo historiográfico". Ver P. Osante, 2015, El noreste fronterizo de México en la época colonial, en Históricas Digital, pp. 51-68, http://www.historicas.unam.mx/publicaciones/publicadigital/libros/escribir/historia.html) que, desde los inicios del siglo XX, ignora los procesos históricos locales o los considera sólo en tanto aportan al relato nacional. En esta tradición historiográfica, el noreste de México suele tomarse en cuenta únicamente cuando se trata de estudiar su participación en la formación del Estado-nación, sobre todo desde que Nuevo León, Coahuila y Tamaulipas se transformaron en frontera. Aunque una parte de la propia historiografía de Nuevo León sigue reproduciendo esa tradición. Ver Eva Rivas et al., "La historia en el noreste y desde el noreste", en Las ciencias sociales en el noreste de México, ed. César Morado Macías y Lucila Hinojosa (Ciudad de México: Universidad Autónoma de Nuevo León - Facultad de Filosofía y Letras, 2016), 105-27. Desde fines de la tercera década del siglo XX dicha historiografía dio un giro regionalista notable con base en el cual se recuperaron las afirmaciones regionalistas de la segunda mitad del siglo XIX (con Vidaurri a la cabeza) y se dio forma a las narrativas de excepcionalidad. A partir de esa década, la historiografía neoleonesa (producida, en buena medida, desde y para Monterrey) empezó a girar del positivismo y la memoria nacional hacia el historicismo y la afirmación de lo local, en parte como respuesta el nacionalismo posrevolucionario. Ver Manuel Ceballos Ramírez, "Monterrey: Realidades y posibilidades historiográficas", en Monterrey 400: estudios históricos y sociales, ed. Manuel Ceballos Ramírez (Monterrey: Universidad Autónoma de Nuevo León, 1998), 69-89; Edgar Iván Espinosa Martínez, "La práctica historiográfica en Nuevo León. Una arqueología del conocimiento histórico regional, 1867-1996”, Secuencia, núm. 68 (2007): 89-114; César Morado Macías, "La historia de Nuevo León. Apuntes epistemológicos sobre la historiografía reciente", Provincias Internas 1, núm. 3 (2001): 13-32.

Sillares, vol. 1, núm. 2, 2022

DOI: https://doi.org/10.29105/sillares1.2-1 
su diferencia con el resto de la nación; es decir, a explicar su peculiar desarrollo comercial e industrial no como resultado de un proceso histórico de acumulación (en el que ocupa un lugar clave su posición en la geografía colonial y nacional, así como el tejido de sus relaciones económicas locales), sino como producto de un ethos inmutable, congelado en el tiempo, que proviene de su peculiar mezcla étnica y de sus relaciones con el medio ambiente hostil; una consecuencia de la lucha en múltiples frentes: contra los indios nómadas, contra la naturaleza, contra el centralismo, contra los anhelos expansionistas norteamericanos. Mientras en el centro del país se consolidaba el nacionalismo posrevolucionario que había heredado (con continuidades y discontinuidades) elementos del patriotismo criollo, ${ }^{31}$ en el margen interno regiomontano se potenciaban narrativas de excepcionalidad que erosionaban dicho nacionalismo, aunque sin apartarse del todo de él. Grosso modo, esas narrativas de sí se caracterizan por oponerse a las fijaciones centralistas de la nación a través de su trabajo con tres imaginarios: étnico-comunitario (nosotros versus ellos), económico-político (lo común versus lo ajeno; el trabajo, la empresa y el Estado) y socio-espacial (adentro versus afuera).

31 David Brading, Los orígenes del nacionalismo mexicano (México, DF: Era, 2004), 1-18; Enrique Florescano, "De la patria criolla a la historia de la nación”, Secuencia, núm. 52 (2002): 7-39.

Sillares, vol. 1, núm. 2, 2022

DOI: https://doi.org/10.29105/sillares1.2-1 
El "nosotros" regiomontano y sus fundamentos económico-políticos son demarcados por la familia, la industria, la laboriosidad, la disciplina, la cultura del trabajo y el origen chichimeca-tlaxcalteca-hispano-(cripto)judío; esto en oposición al "ellos" centralista, huevón, caótico, soberbio, corrupto, ineficiente, proteccionista, autoritario, y originado en lo azteca/ mexica. A su vez, en el imaginario socio-espacial destacan dos campos clave: los geosímbolos (el signo en clave espacial local) y las escalas. A la ausencia de geosímbolos regios en el imaginario central (la nación es Popocatépetl, Iztaccíhuatl, Pico de Orizaba), se le contrapone el Cerro de la Silla como referente que aglutina las más variadas afirmaciones identitarias (podemos recorrer todos los tipos de regionalismo regio y encontrar ahí, en el centro de la representación, a la Silla). En cuanto a las escalas, son tres las que están en juego en la pugna de imaginarios, en la tensión entre oposición y complementariedad entre ellos y en la consecuente imposición de intereses: Monterrey, Nuevo León, Noreste. El despliegue de estas escalas no es lineal ni unidireccional, así Monterrey puede desplegarse como sinécdoque de Nuevo León (y éste como sinécdoque del Noreste), o bien, como sinécdoque de la nación. Esta tensión de escalas nos deja ver que las narrativas de excepcionalidad no se oponen al centralismo como lógica política (Nuevo León mismo es un estado fuertemente centralista), sino al centralismo de la ciudad de México como contenido histórico de la totalidad nacional. 
De entre el denso tejido de narrativas de excepcionalidad, ${ }^{32}$ aquí me detendré en el proyecto nostálgico que Abelardo A. Leal Sr. formuló en El Nuevo Reyno de León: un Estado sin impuestos. Publicado a mitad de la década de los setenta del siglo XX, en pleno enfrentamiento entre la elite económico-política regiomontana y el Estado mexicano, el texto de Leal sintetiza y lleva al extremo las narrativas de excepcionalidad y los imaginarios de la alteridad regiomontana. Es, por lo mismo, el proyecto que más se acerca (en términos de relaciones sociohistóricas de sentido y no de mediaciones tecnológicas) a las afirmaciones identitarias socioespaciales de los espacios regionalistas y separatistas de Facebook. A su vez, el texto como unidad (y, en parte, la obra

32 En Re-sentimientos de la nación... trabajé, además del texto de Abelardo Leal, con las siguientes narrativas de excepcionalidad: Amores, José Emilio (2007). Monterrey: una cultura propia; Arreola, Federico (s.f.). ¿Por qué Monterrey?; Basave del Castillo, Agustín (1945) Constructores de Monterrey; De León, Myriam (1996). Monterrey 400 años: la estirpe de un pueblo, 15961996; De León, Myriam (2007). Orgullosamente bárbaros. Para revalorar el ser y quehacer del norestense; Elizondo Elizondo, Ricardo (1987) Los sefarditas en Nuevo León: reminiscencias en el folklore; García Naranjo, Nemesio (1990 / 1955). Una industria en marcha; Hernández, Timoteo L. (1969). Geografía del Estado de Nuevo León; Novo, Salvador (1965). Crónica regiomontana. Breve historia de un gran esfuerzo; Rangel Frías, Raúl (1988 / 1964). Teorema de Nuevo León; Recio Cavazos, Gabriela (2017). Don Eugenio Garza Sada. Ideas, acción, legado; Rodríguez Muro, Jesús (1965). Geografía política, física y económica del estado de Nuevo León; Roel, Santiago. (1977/1938). Nuevo León, apuntes históricos; Saldaña, José P. (1955). Episodios Contemporáneos; Saldaña, José P. (1973 / 1968). Grandeza de Monterrey y estampas antiguas de la ciudad; Tijerina Almaguer, Luis (1943). Canto al Escudo de Nuevo León; Zapata Novoa, Juan (1993). Tercos y triunfadores de Monterrey: Los retos de Monterrey en el siglo XX.

Sillares, vol. 1, núm. 2, 2022

DOI: https://doi.org/10.29105/sillares1.2-1 
completa de Leal) gira en torno al tema que más moviliza los malestares con el estado nacional de cosas: los impuestos.

\section{El proyecto nostálgico de Abelardo A. Leal, Sr.}

El sábado 17 de julio de 1982 murió Abelardo A. Leal Leal, Sr., abogado autodidacta regiomontano (nacido en Cadereyta en 1899, pero avecindado en Monterrey desde 1921), primer Doctor Honoris Causa de la Universidad Autónoma de Nuevo León (UANL)33 y padre de Abelardo A. Leal. Jr. (1922-1994), quien fuera editor, subdirector y presidente de El Norte durante más de tres décadas.34 En los días posteriores a la muerte de Abelardo Leal, Sr., distintas instituciones locales publicaron esquelas en su honor (entre ellas, la rectoría y la Facultad de Derecho y Ciencias Sociales de la UANL, el Colegio de Abogados de Nuevo León y la Editora El Sol —encargada de la producción, edición, diseño, comercialización y distribución de El Norte-), en las que se le

33 El Doctorado Honoris Causa en Ciencias Jurídicas le fue entregado a Abelardo A. Leal Leal el 2 de junio de 1980, al respecto, una nota de la redacción de El Porvenir narraba el evento enfatizando el relato del hombre que "se hace solo": "Y sucedió aquel modesto autodidacta, caballero sin tacha y modelo de conducta, dejó pasmados a los doctores de la ley, de las ciencias exactas, y los iniciados en los secretos de forma y vida. Cultivador de las disciplinas del Derecho y luchador infatigado de las reclamaciones justas, don Abelardo Leal Leal, produjo ante el Consejo Universitario, depositario por sí de la sabiduría misma, un discurso de elegante y profundo corte académico" (Periódico El Porvenir. "Doctorado merecido", Monterrey, N.L., 3 de junio de 1980).

34 Israel Cavazos Garza, Escritores de Nuevo León. Diccionario bibliográfico (Monterrey: Universidad Autónoma de Nuevo León, 1996), 207.

Sillares, vol. 1, núm. 2, 2022

DOI: https://doi.org/10.29105/sillares1.2-1 
recordaba como un "distinguido jurista nuevoleonés" y "ejemplo en la comunidad regiomontana". ${ }^{35}$

A su vez, M.A. Kiavelo (espacio editorial clave de El Norte y pilar en la construcción de la alteridad regiomontana) empezó su columna del domingo 18 de julio con estas palabras:

1-MIENTRAS dormía, murió ayer sábado, en la madrugada, el Doctor en Ciencias Jurídicas don Abelardo A. Leal, Señor, venerado patriarca de una gran familia del Nuevo Reyno de León.

2-APENAS horas antes don Abelardo había terminado su último libro, sobre cuyo original dejó un recado para que su hijo del mismo nombre lo revise, corrija y proceda a su edición.

1-DURANTE más de sesenta años de estudiar el Derecho sin un día de descanso ni conocer vacaciones, el Doctor Leal buscó la justeza, valor aún más alto y más puro que la imperfecta justicia humana...

2-LA función debe continuar... ${ }^{36}$

A menos de seis meses de la muerte de Abelardo Leal, la Capilla Alfonsina de la UANL publicó una edición no venal de El Nuevo Reyno de León: un Estado sin impuestos, el cual ya había sido impreso en 1975, pero en una edición del propio autor. Esta publicación, según las autoridades de la Capilla Alfonsina, se dio

35 La esquela de la Editora El Sol decía, a la letra: "Editora El Sol, S.A. Se une a la pena que embarga a la Familia Leal Díaz por el sentido pésame de Don Abelardo A. Leal Señor, Q.E.P.D. Padre de nuestro Director Lic. Abelardo A. Leal, Jr. Hacemos votos por el eterno descanso del alma de Don Abelardo A. Leal, Señor, a sabiendas de que su ejemplo y enseñanza han fructificado en su familia y en la comunidad regiomontana, Monterrey, NL., julio 18 de 1982”. 36 Periódico El Norte. M.A. Kiavelo. Monterrey, N.L., domingo 18 de julio de 1982.

Sillares, vol. 1, núm. 2, 2022

DOI: https://doi.org/10.29105/sillares1.2-1 
en retribución a que Leal había donado a la UANL su biblioteca personal (cerca de 13,000 volúmenes) considerada como "la biblioteca jurídica más importante de México". ${ }^{37}$ Debido quizá a la radicalidad del texto de Leal (éste proponía, como veremos, que se le "regresara" a Nuevo León el territorio que le fuera mercedado en 1579), el director de la Capilla Alfonsina sugiere un deslinde: “(el libro) Representa una opinión muy personal de un hecho ya concluido y de sus aparentes consecuencias históricas y políticas... Es el sueño de un hombre estudioso y defensor del Derecho que deseaba en todo aplicar el principio correcto". 38 Pero tres años después, en la presentación de otro libro de Leal, ${ }^{39}$ el mismo Tamez Solís reivindica el texto: "'El Nuevo Reyno de León: un Estado sin impuestos'... detalla como ninguno el desenlace histórico poco difundido sobre la usurpación de derechos y territorio legitimando y distinguiendo la identidad del aridoamericano norestense", ${ }^{40}$

Aunque el proyecto de Abelardo Leal es radical, no imagina desde el vacío. Por el contrario, Leal se nutre del giro regionalista de la historiografía local, de los componentes discursivos de

37 Porfirio Tamez Solís, "Presentación”, en Amparo 71/933: Abelardo A. Leal vs. La ley de la abogacía, ed. Abelardo Leal (Monterrey: Universidad Autónoma de Nuevo León, 1985), 8.

38 Porfirio Tamez Solís, "Presentación", en El Nuevo Reyno de León. Un Estado sin impuestos, ed. Abelardo Leal (Monterrey: Universidad Autónoma de Nuevo León, 1982), IX.

39 Abelardo Leal, Amparo 71 /933. Abelardo A. Leal vs. La ley de la abogacía (Monterrey: Universidad Autónoma de Nuevo León, 1985).

40 Tamez Solís, "Presentación", 1985, 8. [Énfasis mío]

Sillares, vol. 1, núm. 2, 2022

DOI: https://doi.org/10.29105/sillares1.2-1 
las narrativas de excepcionalidad y de los imaginarios étnicocomunitario, económico-político y socioespacial que las cruzan. El siguiente párrafo sintetiza su proyecto nostálgico y la tensión sociohistórica desde donde imagina:

Nuevo León necesita recuperar íntegramente todo el territorio del Nuevo Reyno de León, libre, independiente y soberano como naciera, para liberarlo del pavoroso endeudamiento y del terrible desastre político, económico, moral y administrativo de la suzeranía de Moctezuma y Cía., S.A., que impera con su centralismo en la eterna Tenochtitlán, D.F. Y crear con dicho Nuevo Reyno de León un país de trabajo, producción, crédito, unión, y progreso tradicionales de Nuevo León. Un Estado sin impuestos, solidarista, del deber de superación y de la superación del deber, que nos lleve a cada uno y a todos al común mejoramiento, prosperidad y concordia, cuya categoría y solvencia le dé lugar en el Primer Mundo Internacional. ${ }^{41}$

A grandes rasgos, lo que Abelardo Leal propone es demandar ante la Corte Internacional de Justicia y la Organización de las Naciones Unidas que a Nuevo León se le "restituya" el territorio mercedado a Luis Carvajal y de la Cueva en 1579 bajo el rubro del "Nuevo Reyno de León", una demanda que haría que Nuevo León contara con una parte importante del norte de México e, incluso, de Texas: "desde el Puerto de Tampico al Norte por el litoral del Golfo de México y sus doscientas leguas en cuadro hacia el interior". ${ }^{42} \mathrm{Y}$ es que, para Leal, el Estado colonial y el Estado nacional se dedicaron,

41 Leal, El Nuevo Reyno León. Un Estado sin impuestos, 50. [Énfasis mío] 42 Leal, 15.

Sillares, vol. 1, núm. 2, 2022

DOI: https://doi.org/10.29105/sillares1.2-1 
desde sus inicios, a "usurpar" y "mutilar" el territorio de Nuevo León ${ }^{43}$ : "no podemos aceptar la mutilación de nuestro territorio del 'Nuevo Reyno de León', a la migaja de sierra y tepetate, carente de recursos naturales, en que los atentados de todos los tiempos culminados con el encono de Juárez en 1864, nos han dejado reducidos". ${ }^{44}$ Leal utiliza el pasado colonial para diseñar un futuro republicano del terruño, para desplegar un "como si" $^{45}$ en el cual Nuevo León nunca ha dejado de ser, en espíritu, el "Nuevo Reyno de León" y en el que la excepcionalidad regiomontana se expande sobre casi todo el norte de México y parte del sur de Estados Unidos. Bajo el supuesto de que Nuevo León fue despojado ilegítimamente de su territorio, Leal declara "inexistentes los repartos virreinales $\mathrm{y}$ republicanos, las traidoras enajenaciones y todos los pactos seudoconstitucionales, que afecten al auténtico territorio de Nuevo León, que debe ser el de su originario 'Nuevo Reyno de León"”. 46

43 Hay que decir que la idea de "mutilación” es clave no sólo en el imaginario socioespacial de la alteridad regiomontana, sino también en el imaginario socioespacial de la nación, en concreto, a partir a la "mutilación" del territorio que el país "sufrió" al perder la guerra con los Estados Unidos.

44 Leal, El Nuevo Reyno León. Un Estado sin impuestos, XI.

45 El "Como si" radica en lo que Ricoeur define como el "es" metafórico: toda metáfora, a la par, "no es" y "es como" aquello que reemplaza. Y es esa tensión constante de "no ser" y "ser como" la que le da su poder de redescripción de lo real al jugar con las fronteras de lo posible y de lo imposible: "el 'lugar' de la metáfora, su lugar más íntimo y último, no es ni el nombre ni la frase ni siquiera el discurso, sino la cópula del verbo ser. El 'es' metafórico significa a la vez 'no es' y 'es como'". Ver Paul Ricoeur, La metáfora viva (Madrid: Ediciones Europa, 1980), 15.

46 Leal, El Nuevo Reyno León. Un Estado sin impuestos, XI.

Sillares, vol. 1, núm. 2, 2022

DOI: https://doi.org/10.29105/sillares1.2-1 
Dada la importancia estratégica del acceso al mar, Leal dibuja un cuadrante en el que (a diferencia del trazado por Vito Alessio Robles a fines de la década de los veinte) se traza el "territorio verdadero" del Nuevo Reyno de León en un área que le otorga la posesión completa de los derechos marítimos del Golfo:

A nosotros nos interesa superlativamente el litoral del golfo de México que marca Tampico, por la categoría marina que tiene el Nuevo Reyno de León con dicha playa y su comunicación directa internacional, viajera, turística, postal, mercantil, jurídica, defensiva y demás contacto con la familia mundial, así como por las doscientas leguas de mar territorial, que son una riqueza pesquera y de autosubsistencia, amén que no sería remoto también petrolera. ${ }^{47}$

En el imaginario socioespacial de la excepcionalidad regiomontana, la escala del "Nuevo Reyno de León" ocupa un lugar clave como práctica de imaginación (no es ninguna casualidad que, en voz de M.A. Kiavelo, El Norte haya recordado a Leal, según mostré atrás, como un "venerado patriarca de una gran familia del Nuevo Reyno de León"). En tanto práctica del como si, el "Nuevo Reyno de León" es un espacio mítico (una metáfora espacial que nunca hizo territorio) que conecta al Nuevo León del presente (y en particular a Monterrey) con el del espacio idealizado del siglo XVI. Esta forma de retroactividad, de imaginación política nostálgica basada en el como si, se activa para hablar de los malestares con el estado nacional de cosas. Y su

47 Leal, 22.

Sillares, vol. 1, núm. 2, 2022

DOI: https://doi.org/10.29105/sillares1.2-1 
tema típico de activación son los impuestos y el relato de la injusticia fiscal. ${ }^{48}$ En su columna En pocas palabras, publicada en Milenio, Miguel Ángel Vargas escribe desde esta posición de imaginación que vincula el ethos regiomontano y sus esencializaciones atemporales (el relato de adversidad, la cultura del esfuerzo) con la retroactividad al Nuevo Reyno de León a través de los impuestos:

En más de una ocasión me han preguntado si los nuevoleoneses somos codos y les respondo con un contundente no. Los nativos de esta región del país siempre hemos sido ordenados con el gasto y hasta nos alcanza para ahorrar. Nuestros ancestros llegaron a estas tierras en condiciones difíciles. Acá todo escaseaba: el dinero, el agua, la vegetación, y con trabajo y mucha tenacidad pudieron salir adelante.... Como la mía, hay miles de historias parecidas, y podrán identificarse con esa cultura del trabajo y tesón de quienes habitamos el llamado Nuevo Reino de León. A nivel nacional se nos reconoce como gente emprendedora, porque así somos. Por eso molesta que el Gobierno Estatal piense cobrarnos hasta por prender el carbón... Al buen administrador... menos impuestos. ${ }^{49}$

48 Lo importante, en términos del análisis sociohistórico de las narrativas de excepcionalidad, no es si Nuevo León realmente da más de lo que recibe o no (o si podría vivir sin los recursos de otros), lo relevante es que los que afirman que el trato es injusto asumen que lo que dan es para los otros, los que siempre han estado lejos, los que agreden, amenazan, devoran, invaden, de diversas formas, al "nosotros" local y regional. En el relato según el cual los neoleoneses "mantienen al país" (con su cultura de trabajo forjada históricamente en condiciones de adversidad) se ponen en juego los límites de la nación en tanto comunidad política imaginada.

49 Periódico Milenio. "NL: al buen administrador". Monterrey, N.L., 20 de diciembre de 2017. [Énfasis mío].

Sillares, vol. 1, núm. 2, 2022

DOI: https://doi.org/10.29105/sillares1.2-1 
Esta afirmación del "Nuevo Reyno de León", que alude a la supuesta grandeza perdida de Nuevo León, está emparentada, a su vez, con otra afirmación utilizada con frecuencia en la línea editorial de El Norte, la cual se refiere a su estado vecino como "la parte de Nuevo León que ahora se llama Coahuila”. Sin importar el tema específico del que se trate, es usual que se utilice esta expresión ${ }^{50}$ poniendo en primer plano la relación todo/partes y la dimensión temporal antes/ahora que recuerda el periodo vidaurrista en el que Nuevo León y Coahuila fueron una sola entidad federativa (1856-1864), ${ }^{51}$ hasta que Benito Juárez "los separó".

50 Estos son algunos ejemplos utilizados en M.A. Kiavelo, sólo en 2017: "Donde no deja de temblar es en la parte de Nuevo León que ahora se llama Coahuila"; "En la parte de Nuevo León que ahora se llama Coahuila, el Gobernador Rubén Moreira no tiene empacho en declarar que el Obispo Raúl Vera..."; "En la parte de Nuevo León que ahora se llama Coahuila existe preocupación entre el electorado porque Miguel Riquelme..."; “Al Gobernador Jaime Rodríguez le está ganando la querencia por la parte de Nuevo León que ahora se llama Coahuila...".

51 Diego Osorno ya ha señalado esta afirmación identitaria como parte de la relación entre el (neo)vidaurrismo y la línea editorial de El Norte. Comparando a Santiago Vidaurri con José Alvarado (ambos originarios de Lampazos de Naranjo, Nuevo León), Osorno afirma: "El autoritarismo, el aislacionismo y la traición a la patria que caracterizaron al vidaurrismo del siglo XIX todavía son algo común en el Nuevo León del siglo XIX... En este Lampazos de sátrapas revividos y esculpidos, cómo se extraña a José Alvarado... Si Lampazos dio un tirano, Lampazos dio también a un humanista. Por cada Santiago Vidaurri hay un José Alvarado... Los neovidaurristas de entonces [1961] se alarmaron y conspiraron contra él [José Alvarado]. Hoy siguen en el poder, haciendo como que gobiernan Nuevo León con sus empresas, con sus cargos en el gobierno y su periódico, ese que suele afirmar, sin pudor: 'La parte de Nuevo León que ahora se llama Coahuila..."” (Periódico Milenio Monterrey. "Entre Santiago Vidaurri y José Alvarado". Monterrey, N.L., 5 de agosto de 2007).

Sillares, vol. 1, núm. 2, 2022

DOI: https://doi.org/10.29105/sillares1.2-1 
Lo que subyace a esta afirmación identitaria socioespacial es el siguiente supuesto: Vidaurri no anexó Coahuila a Nuevo León ante la debilidad del gobierno central, sino que lo "recuperó".

Así, alimentándose del imaginario regionalista socioespacial, Abelardo Leal realiza un ejercicio de imaginación en el que el pasado idealizado y congelado en el tiempo (E1 Nuevo Reyno de León) debe ser recuperado como salida a los problemas de su presente (centralismo, burocracia, priismo, corrupción, endeudamiento). En su texto, Leal no se refiere nunca al centro del país sin añadirle sustantivos vinculados con el campo semántico de lo azteca/mexica, incluso sobreponiéndolos ("La seudofederación de Moctezuma, D.F."; "feudal castillo de Chapultepec" "D.F de la Azteca Tenochtitlán"). Así, la tensa visita que realizó Echeverría a Monterrey al final de su mandato es registrada por Leal con base en el tiempo congelado del espacio colonial, como una más de las múltiples afrentas que el "mutilado" y prístino Nuevo León ha tenido que sufrir desde fines del siglo XVI:

Don Luis y el Nuevo Reyno de León aún existen en la memoria de sus sucesores. De ese extenso territorio aún queda como 'hijastro' de la seudo-República Mexicana, sucesor del Nuevo Reyno de León, el pequeño y yermo Nuevo León, que, decíamos, se ha convertido en la Capital Industrial de México. Los resabios perduran: en 1976 vino Moctezuma Echeverría a derramar su ira y su soberbia sobre los 'riquillos' de Nuevo León. ${ }^{52}$

52 Leal, El Nuevo Reyno León. Un Estado sin impuestos, 4.

Sillares, vol. 1, núm. 2, 2022

DOI: https://doi.org/10.29105/sillares1.2-1 
A ese "ellos" del centralismo, Leal le opone un doble "nosotros": el del Nuevo León de mediados de la década de los setenta del siglo XX (desde el que escribe) y el del Nuevo Reyno de León de 1579. En el primero, Nuevo León está definido por la "usurpación" y las "miserias" que tanto el centralismo colonial como el nacional dejaron al "mutilar" al Nuevo Reyno de León: "Nos privaron de diez onceavas partes del Nuevo Reyno de León, dejando a Nuevo León la onceava restante, lo más estéril, pequeño para que nunca fuera grande, y encerrado al interior sin los pulmones al Golfo de México que tenía el Nuevo Reyno de León para su libre y fácil relación internacional". ${ }^{53}$ Las únicas valoraciones positivas que Leal hace de este Nuevo León despojado, reducido a ser "piedra y tepetate", tienen que ver con el progreso, el trabajo como orgullo industrial ${ }^{54}$ y la continuidad étnica de lo que podríamos definir como el mestizo fronterizo, el cual no sólo es visto como menos mestizo que el del centro y sur del país, sino como hecho de otra hispanidad y de otras herencias indígenas - "la raza primordial del Nuevo Reyno de León”, mezcla de "ancestrales

53 Leal, 3.

54 "Carvajal y de la Cueva... fue el primer paladín que con dicho 'Reino' abrió la puerta del Mundo a este erial magnético, que de su propia entraña rocosa genera todo este potencial humano de trabajo, industria, comercio, economía, cultura y demás factores de prosperidad tan admirables y ejemplares, hermosa heráldica que cual paradoja modesta y orgullosa, se dibuja en el espacio con sus chimeneas fabriles, como veladoras rezanderas, elevando constantes e incansables el humo de su laboriosa oración, al cielo infinito del desarrollo y del progreso". Ver Leal, 14.

Sillares, vol. 1, núm. 2, 2022 
judíos conversos carvajales" y de "indios chichimecas incansables de trabajo" 55 :

Nuevo León, pertenencia de Tenochtitlán nomás tú nunca fuiste. Tus indómitas tribus conexión jamás tuvieron con aztecas. Tributo ni obediencia alguna a Moctezuma tú reconociste. Eres campo independiente, dominio de indios libres chichimecas. Tus hombres nacen en medio de tus pobres charales y tus breñas; Aborígenes que un día vieron la llegada de los Carvajales que aportaron su cultura y su industria hacia estas escabrosas peñas, e hicieron un emporio de riqueza de estos tuyos pedregales. Con chichimeco-carvajales se inició aquel Nuevo Reyno de León. ${ }^{56}$

A ese pedacito de sí, Leal lo complementa con el "nosotros" del Nuevo Reyno de León esencializado, ahistórico, mítico. El espíritu "verdadero" del ethos neoleonés se caracteriza, desde esta práctica retroactiva, por la soberanía, la libertad y la autonomía perdidas, arrebatadas, y tiene como institución nodal a la familia y a Carvajal como padre fundador. Para recuperar ese "nosotros" de fines del siglo XVI, Leal imagina un "Estado solidarista" (basado en la obra del político paraguayo Juan Stefanich) sin impuestos ni huelgas, centrado en el modelo de la familia como unidad básica gobernada por un pater justo. $\mathrm{Y}$ en esta familia utópica no caben las prácticas del comunismo que contradicen la "bendita desigualdad" 57 y las libertades individuales: "ya no tratemos de enmendarle la Plana al Padre Eterno, con una 'sociedad \begin{tabular}{ll}
\hline 55 & Leal, $1,132$. \\
56 & Leal, 155. \\
57 & Leal, 153.
\end{tabular}

Sillares, vol. 1, núm. 2, 2022

DOI: https://doi.org/10.29105/sillares1.2-1 
igualitaria'... La desigualdad humana es la maravilla de la Obra: no somos animales, ahí está la maravilla de la superación: cada quien llegará hasta donde quiera y con su propia superación". 58 El Nuevo Reyno de León se ejerce, así, como un lugar para imaginarse sin las amenazas y restricciones del Estado mexicano, sin "Moctezuma-Echeverría" y todos sus antecesores.

En este doble despliegue del "nosotros" local, Leal concibe a Nuevo León como un todo esencializado y mutilado que antecede al Estado de Nuevo León como parte del todo nacional. Al mito del Centro le antepone el mito neoleonés, pero lo hace bajo la figura del Nuevo Reyno que imagina como presente y ausente al mismo tiempo. Lo que han hecho el Estado colonial y el Estado nacional ha sido, en su continuidad centralista, reducir a una parte lo que en realidad siempre ha sido un todo (un todo que, incluso, antecede al todo que lo contiene). Por eso, en su pelea con el regionalismo centralista de la ciudad de México, Leal se desplaza constantemente entre el regionalismo autonómico (el cual reclama ampliar su campo de acción sin romper con el todo que lo contiene) y el separatismo: "Y si reo me condenan porque de la unión tratamos de salirnos, o traidor me declaran a esa patraña centralista nacional, que entiendan que un pacto es un contrato que a su vez tienen que cumplirnos con el mayor respeto de nuestro soberano derecho estatal" ${ }^{59}$ Esta tensión entre regionalismo autonómico y

$\begin{array}{ll}58 & \text { Leal, } 74 . \\ 59 & \text { Leal, } 156 .\end{array}$

Sillares, vol. 1, núm. 2, 2022

DOI: https://doi.org/10.29105/sillares1.2-1 
separatismo no se resuelve nunca en el texto de Leal; en su pluma, el Nuevo Reyno de León a veces es nación y a veces es región. ${ }^{60}$

Por todo lo anterior, dejar de pagarle impuestos al "colonialismo federal", al "comunismo centralista", ${ }^{61}$ es para Leal la salida económico-política del laberinto nacional, el destino mítico del mestizo fronterizo y el regreso a la grandeza perdida:

Si los judíos de Israel han hecho un emporio de riqueza con un gotero en el desierto del Sinaí, los nuevoleoneses como buenos judíos "de las tres mitades": mitad chichimecos, mitad caldeos y mitad cristianos, simplemente agarrados de la brocha trataremos de hacer de este peñasco de Nuevo León un estado sin impuestos... Sin impuestos Nuevo León surgiría a la abundancia, abarataría indudablemente su costo de la vida, y estaríamos en condiciones más ventajosas de introducción hasta en los más desarrollados mercados exteriores. Han estirado tanto la cuerda, es tan grande el abuso federal contra Nuevo León que ellos mismos con su desmesurado tributo nos han abierto el camino de la liberación. Que si logramos recuperar el Nuevo Reyno de León, con puertas al mar y mar territorial, y con libertad, independencia y soberanía verdaderas, podríamos conquistar algún lugar digno y meritorio en la familia tradicional. ${ }^{62}$

60 Leal le dedicó, al menos, quince años a este proyecto reivindicatorio (para fines de la década de los sesenta ya publicaba en El Norte artículos que hablaban de la necesidad de "recuperar" el mar de Tamaulipas). Además de $E l$ Nuevo Reyno de León, un estado sin impuestos, Leal publicó en 1979 tres tomo de Moctezuma, D.F.: el fraude agrario de México, textos en los que reconstruye, desde la herida local, la historia del centralismo mexicano: “ $¡ M$ Moctezuma, D.F., D.F., D.F.! cuyo 'D.F.' lo mismo puede ser despotismo, desastre que desgobierno federal, u otro sinnúmero de 'des' siempre negativos... Un pulpo que como capataz vive a costa de las provincias tributarias".

${ }_{61}$ Leal, El Nuevo Reyno León. Un Estado sin impuestos, 131.

62 Leal, 136-38.

Sillares, vol. 1, núm. 2, 2022

DOI: https://doi.org/10.29105/sillares1.2-1 
$\mathrm{Y}$ es que, tanto para el regionalismo autonómico como para el separatismo, pagar los impuestos a la federación no es visto sólo como un desperdicio, sino también como una injusticia porque implica "mantener" a los otros, ${ }^{63}$ a los "huevones" del centro-sur, a pesar del maltrato histórico recibido por ellos: "Sería injusto que los Estados más laboriosos paguen por la indolencia, la desidia o el desinterés de los demás, peor cuando estos últimos tengan mejores recursos naturales, y por ello vivan despreocupados ante la prodigalidad de su territorio". ${ }^{64}$

El proyecto nostálgico de Abelardo Leal ha circulado, explícitamente, en los grupos y páginas separatistas de Facebook. Pero, más allá de esta presencia directa, lo importante es que ambos espacios de enunciación comparten, con sus desplazamientos de sentido, los mismos componentes clave de las narrativas de excepcionalidad: el relato de la adversidad como obstáculo productivo para forjar el carácter, la cultura del trabajo y del esfuerzo, el ethos del mestizo fronterizo que privilegia la hispanidad, ${ }^{65}$ la reivindicación de la individualidad y de la libertad económica como principio de todas las

63 Es a esta tensión entre los límites del nos-otros local y el nos-otros nacional, en tanto comunidades políticas imaginadas, a la que alude Leal cuando utiliza, a modo de epígrafe, la sentencia del jurista romano Domicio Ulpiano: "Nadie es compelido/ contra su voluntad/ a la comunidad con otro". Ver Leal, 6.

64 Leal, 131.

65 "Consideramos que nuestro origen cultural es el Nuevo Reino de León, fundado en 1582. Así mismo abogamos por la unión de los pueblos hispanos, pugnamos por la unión en la diversidad desarrollada por siglos en la Nueva España, respetando la identidad cultural de los pueblos que formaron este territorio", afirman en la página de Facebook Orgullo Neoleonés (19 de abril de 2018).

Sillares, vol. 1, núm. 2, 2022

DOI: https://doi.org/10.29105/sillares 1.2-1 
libertades, la oposición al centralismo no sólo en términos políticos y económicos, sino también culturales y étnicos ${ }^{66}$ la tensión constante entre el regionalismo autonómico y el separatismo, la centralidad temática de los impuestos y el relato de la "injusticia" fiscal, ${ }^{67} \mathrm{el} \mathrm{es-}$ tado-centrismo (con Monterrey como eje y espacio en expansión) ${ }^{68}$ y la densidad histórico-cultural de sus referentes. ${ }^{69}$

66 "Lo chilango" y "lo mexica" funcionan como la frontera externa constitutiva, la negatividad absoluta, sobre la que se construye buena parte del sentido de estas narrativas.

67 En los espacios sociodigitales, el tema de los impuestos y el relato de la injusticia fiscal están vinculados semánticamente, al igual que en el texto de Abelardo Leal, con el robo - "nos roban 250 mil millones cada año", afirman en República de Nuevo León (10 de abril 2019)—; con la obligación de "mantener" a los "huevones" del centro/sur; con la "mutilación" de Nuevo León —al cual debería pertenecerle Tamaulipas y Coahuila: "Nuevo León era más grande, Juárez nos redujo por sus pistolas, deberíamos ser un estado independiente o país" (República de Nuevo León, 10 de abril de 2019)—, así como con la mala administración y corrupción del gobierno central: "Hoy en día somos esclavos del imperio mexica... el gobierno centralista solo se encarga de quitarnos nuestros impuestos, para malgastarlos pagándole a cientos de senadores y diputados inservibles" (Viva La República Del Río Grande, 6 de julio de 2010).

68 La oposición al centralismo que cruza el texto de Leal y, a su vez, a todos los grupos y páginas separatistas no tiene que ver con la idea de estar en contra de toda relación de fuerzas en la que un centro domina las marginalidades que produce, sino más bien con el centralismo de lo "chilango" (azteca, mexica, mesoamericano). De hecho, la imaginación política separatista suele basarse en otra centralidad: Monterrey y lo regiomontano (con el Cerro de la Silla como geosímbolo aglutinante). Desde la perspectiva de estas narrativas, el centralismo chilango/sureño no sólo es muy diferente al eje regional Monterrey/Nuevo León/Noreste, sino que amenaza, como toda diferencia radical, su existencia.

69 En todos los grupos y páginas separatistas se imagina con base en la mezcla de los siguientes referentes de unidad: Santiago Vidaurri (aglutinante de Sillares, vol. 1, núm. 2, 2022

DOI: https://doi.org/10.29105/sillares1.2-1 
Existe, sin embargo, una diferencia clave entre ambos lugares de enunciación. Abelardo Leal concibió y escribió su texto, desde una posición central, entre mediados de la década de los sesenta y mediados de la década de los setenta, cuando la elite económico-política regiomontana y los aires de progreso industrial aún controlaban buena parte de la vida pública local y los anhelos regios, cuando el llamado Grupo Monterrey (con Eugenio Garza Sada a la cabeza) era capaz de enfrentarse con toda su fuerza al gobierno central y los rumores sobre un golpe de Estado orquestado desde "La Sultana" revoloteaban tanto en la prensa como en los humores políticos capitalinos. Los promotores del separatismo en redes sociodigitales, en cambio,

la autonomía norestense, de la lucha contra el centro y contra los indios seminómadas), La supuesta República del Río Grande (y, en menor medida, la República de la Sierra Madre), El Cerro de la Silla (geosímbolo que alude a la majestuosidad del ethos neoleonés), el León Rampante (sinécdoque del escudo del estado), El lema Semper Ascendens (o su castellanización "siempre ascendiendo"), El Nuevo Reyno de León (como práctica nostálgica, de retroacción a la "grandeza" perdida de Nuevo León) y Aridoamérica (como espacialización de la diferencia y alteridad Mesoamérica). Estos elementos, o combinaciones entre ellos, nutren la imaginación política separatista hasta la saturación. De igual forma, los creadores de estos grupos suelen ejercer el anonimato no sólo en tanto forma de ocultamiento, sino también como práctica de representación, aprovechando la plasticidad identitaria que permiten estas "superficies de inscripción digital". Ver Rossana Reguillo, Paisajes insurrectos. Jóvenes, redes y revueltas en el otoño civilizatorio (Barcelona: Nuevos Emprendimientos Editoriales, S. L., 2017). Es común, entonces, que sus nombres o sus imágenes de perfil estén compuestos por referentes aglutinantes de la imaginación política separatista (mapas de Aridoamérica y del Nuevo Reyno de León, banderas de la República del Río Grande, fotos de Vidaurri, representaciones de un León Rampante, imágenes del Cerro de la Silla, y sus múltiples combinaciones).

Sillares, vol. 1, núm. 2, 2022

DOI: https://doi.org/10.29105/sillares1.2-1 
sostienen el relato del orgullo industrial cuando las condiciones materiales de la ciudad ya han cambiado (transitando hacia una economía de servicios de carácter global), cuando el poder de la elite (aún importante) se ha dispersado, y, sobre todo, lo hacen en condiciones de precariedad, alejados de las mieles del progreso industrial sobre las que se cocinaron las narrativas de excepcionalidad, dedicados a gestionar fragmentos de memoria en espacios de replicación digital relativamente autocontenidos, acostumbrados a hacer memes que no se viralizarán, a crear grupos y páginas con poco alcance y que pueden ser cerrados en cualquier momento por denuncias de incitación al odio, a organizar reuniones a las que llegarán unas cuantas personas. ${ }^{70}$

En síntesis, y más allá de las diferencias en cuanto al lugar de enunciación, se trata, en ambos casos, de proyectos nostálgicos que nos hablan de fisuras en la comunidad política imaginada de lo mexicano; proyectos nostálgicos hechos de prácticas de retroacción, los cuales buscan hacerle justicia a un pasado mítico que, desde su perspectiva, nunca se fue del todo: el Nuevo Reyno de León o la República del Río Grande; proyectos a través de los cuales se conversan los malestares con el estado nacional de cosas y se imaginan, desde un pasado esencializado,

\footnotetext{
70 "Hacer esto era una friega, salíamos en tiempos de frío, o, en plena resolana, a veces con hambre, cansados porque toda la semana trabajábamos, y el único día de descanso salíamos a cumplir con esto, a veces cancelábamos compromisos familiares por esto", cuenta uno de los promotores del Movimiento Nacionalista Riograndense (30 de julio del 2013).

Sillares, vol. 1, núm. 2, 2022

DOI: https://doi.org/10.29105/sillares1.2-1
} 
las salidas del laberinto, fuera del pacto nacional y de sus apuestas comunitarias.

\section{Consideraciones finales}

En este ensayo he propuesto abordar el proyecto nostálgico de Abelardo A. Leal, Sr. no como una práctica excéntrica, anacrónica o absurda, sino como una parte del tejido histórico-cultural de las narrativas de la excepcionalidad regiomontana. Y, con esa misma intención, he trazado algunas relaciones sociohistóricas de sentido entre dicho proyecto y los espacios sociodigitales que promueven la separación de Nuevo León o del noreste como un todo. He insistido en que esas relaciones de sentido nos hablan de proyectos nostálgicos que, a través del regreso figurado a un pasado mítico y esencializado, dibujan grietas en aquello que Benedict Anderson llamó las "comunidades políticas imaginadas" y nos permiten re-pensar la formación cotidiana del Estado-nación en México, en toda su contingencia, como proyecto inconcluso y narrativa sociocultural.

Como nota final, quisiera poner sobre la mesa tres motivos más por los que considero necesario apostar por una perspectiva de análisis sociohistórico que trace relaciones de sentido en afirmaciones identitarias socioespaciales de carácter aparentemente marginal (las cuales, si sólo nos enfocáramos en su inmediatez e inmanencia, o bien en sus condiciones de posibilidad según la política clásica, aparecerían como anacrónicas e irrelevantes). Esta perspectiva es necesaria, en Sillares, vol. 1, núm. 2, 2022 
primer lugar, porque las fronteras internas producidas como parte de estos proyectos nostálgicos (dentro del denso tejido de las narrativas de excepcionalidad y de las narrativas centralistas de la nación) no son enunciaciones discursivas que flotan libremente sin mayor impacto, sino que generan violencias y racismos cotidianos que buscan la eliminación simbólica (y en ocasiones física) del otro, como el único modo de poder regresar a un "nosotros" ahistórico y esencializado (prácticas raciales, por ejemplo, contra los migrantes del centro-sur del país que llegan a la urbe regiomontana a trabajar, en condiciones de precarización, en la economía de servicios).

En segundo lugar, esta perspectiva es necesaria porque las afirmaciones identitarias separatistas de corte radical (marginales, pero íntimamente relacionadas con el núcleo de las afirmaciones regionalistas que circulan por la alteridad regiomontana) nos hablan de una fisura en la parte regia que, con el tiempo, podría crecer más allá de la arena política local. En tercer y último lugar, esta perspectiva es cada vez más importante ante el llamado "giro global a la derecha" de los últimos años, lo cual nos obliga, más que nunca, a estudiar estos fenómenos locales en los que se reactivan afirmaciones reaccionarias que, en el marco de la formación del Estado-nación en México, tienen que ver con el resurgimiento de aquellos nacionalismos conservadores, hispanófilos (tanto de elite como populares) que aparentemente "perdieron la batalla" contra el nacionalismo posrevolucionario, pero que nunca se han ido del todo.

Sillares, vol. 1, núm. 2, 2022

DOI: https://doi.org/10.29105/sillares1.2-1 


\section{Referencias}

"Viva la República del Río Grande". Facebook. Consultado el

12 de julio de 2019. https://www.facebook.com/Viva-La-Republica-Del-Rio-Grande-107473882607780/.

“Rugido de León". Facebook. Consultado el 16 de agosto de 2019. https://www.facebook.com/RugidoNL/videos/2343276099244680.

"República de Nuevo León". Facebook. Consultado el 10 de abril de 2019. https://www.facebook.com/República-de-Nuevo-León-1397065107195153/.

"Orgullo Neoleonés". Facebook. Consultado el 19 de abril de 2018. https://www.facebook.com/NeoLeonesPride/.

"Movimiento Nacionalista Riograndense". Facebook. Consultado el 30 de julio de 2013. https://www.facebook.com/Movimiento-Nacionalista-Riograndense-346863968721525/ .

Aboites Aguilar, Luis. "En busca del centro. Una aproximación a la relación centro-provincia en México, 1921-1949". Historia Mexicana 59 (2009): 711-54.

Anderson, Benedict. Comunidades imaginadas. Reflexiones sobre el origen y la difusión del nacionalismo. México, DF: Fondo de Cultura Económica, 1993.

Brading, David. "Patriotismo y nacionalismo en la historia de México". En Actas del XII Congreso de la Asociación Internacional de Hispanistas, 1-18. Birmingham, 1995.

Brading, David. Los orígenes del nacionalismo en mexicano. México, DF: Era, 1983.

Briones, Claudia. "Formación de alteridad, contextos globales, procesos nacionales y provinciales". En Cartografías argentinas. Políticas indigenistas y formaciones provinciales de alteridad, 10-39. Buenos Aires: Antropofagia, 2005.

Castells, Manuel. Comunicación y poder. Madrid: Alianza, 2009. Sillares, vol. 1, núm. 2, 2022 
Castro-Gómez, Santiago. "Ciencias sociales, violencia epistémica y el problema de la invención del otro". En La colonialidad del saber. Eurocentrismo y ciencias sociales. Perspectivas latinoamericanas, 88-98. Bogotá: Consejo Latinoamericano de Ciencias Sociales, 2000.

Cavazos Garza, Israel. Escritores de Nuevo León. Diccionario bibliográfico. Monterrey: Universidad Autónoma de Nuevo León, 1996.

Cavazos Garza, Israel, y César Morado Macías. "Introducción”. En Fábrica de la frontera. Monterrey, capital de Nuevo León (1596-2006), 17-20. Monterrey: Ayuntamiento de Monterrey, 2006.

Ceballos Ramírez, Manuel. "Visiones contradictorias del norte mexicano: elementos de una historia cultural". En Historia, región y frontera norte de México, 193-220. México, DF: Bonilla Artigas; Universidad Autónoma de Tamaulipas, 2011.

Ceballos Ramírez, Manuel. "Monterrey: Realidades y posibilidades historiográficas". En Monterrey 400: estudios históricos y sociales, editado por Manuel Ceballos Ramírez, 69-89. Monterrey: Universidad Autónoma de Nuevo León, 1998.

Cerutti, Mario. Burguesía y capitalismo en Monterrey (18501910). México, DF: Claves Latinoamericanas, 1983.

Cerutti, Mario. Burguesía, capitales e industria en el norte de México. Monterrey y su ámbito regional (1850-1910). Monterrey: Universidad Autónoma de Nuevo León; Alianza, 1992.

Espinosa Martínez, Edgar Iván. "La práctica historiográfica en Nuevo León. Una arqueología del conocimiento histórico regional, 1867-1996”. Secuencia, núm. 68 (2007): 89-114.

Sillares, vol. 1, núm. 2, 2022

DOI: https://doi.org/10.29105/sillares1.2-1 
Florescano, Enrique. "De la patria criolla a la historia de la nación”. Secuencia, núm. 52 (2002): 7-39.

Florescano, Enrique. Etnia, estado y nación. México, DF: Taurus, 2008.

García Alonso, María. "Los territorios de los otros: memoria y heterotopía". Cuicuilco 21, núm. 61 (2014): 333-52.

García Martínez, Bernardo. "El espacio del (des)encuentro". En Encuentro en la frontera: mexicanos y norteamericanos en un espacio común, 19-51. México, DF: El Colegio de México - Centro de Estudios Históricos; El Colegio de la Frontera Norte; Universidad Autónoma de Tamaulipas, 2001.

García Martínez, Bernardo. El desarrollo regional, siglos XVI al XX. México, DF: El Colegio de México, 2004.

García Martínez, Bernardo. Las regiones de México. Breviario geográfico e histórico. México, DF: El Colegio de México, 2008. Grimson, Alejandro. Los límites de la cultura. Críticas de las teorías de la identidad. Buenos Aires: Siglo XXI, 2011.

Jenkins, Henry. Convergence Culture. La cultura de la convergencia de los medios de comunicación. Barcelona: Paidós, 2008.

Leal, Abelardo. Amparo 71 1933. Abelardo A. Leal vs. La ley de la abogacía. Monterrey: Universidad Autónoma de Nuevo León, 1985.

Leal, Abelardo. Moctezuma, D.F.: el fraude agrario de México. Monterrey: Impresora y Editorial Plata, 1979.

Leal, Abelardo. El Nuevo Reyno de León. Un Estado sin impuestos. Monterrey: Universidad Autónoma de Nuevo León, 1982.

López Feldman, Aarón. "Re-sentimientos de la nación. Regionalismos, separatismos e imaginación política en narrativas de la excepcionalidad regiomontana". Instituto Tecnológico y de Estudios Superiores de Occidente, 2019. http:// hdl.handle.net/11117/6050.

Sillares, vol. 1, núm. 2, 2022 
Monsiváis, Carlos. “¿Qué se fizo de la provincia?”El Universal. el 26 de abril de 2009. http://archivo.eluniversal.com.mx/editoriales $/ 43850 . \mathrm{html}$.

Morado Macías, César. "La historia de Nuevo León. Apuntes epistemológicos sobre la historiografía reciente". Provincias Internas 1, núm. 3 (2001): 13-32.

Ortiz, Renato. Otro territorio. Ensayos sobre el mundo contemporáneo. Bogotá: Convenio Andrés Bello, 1998.

Osante, Patricia. "El noreste fronterizo de México en la época colonial". En El noreste fronterizo de México en la época colonial, 51-68. México, DF: Universidad Nacional Autónoma de México - Instituto de Investigaciones Históricas, 2009.

Palacios, Lylia. "La Muerte obrera en Monterrey". Académicxs de Monterrey 43, 2017. https://academicxsmty43.blog/2017/11/20/ la-muerte-obrera-en-monterrey-lylia-palacios/.

Raichenberg, Enrique, y Catherine Héau-Lambert. "La frontera en la comunidad imaginada del siglo XIX". Frontera Norte 19, núm. 38 (s/f): 37-61.

Ramírez, Eduardo. El triunfo de la cultura. Uso político y económico de la cultura en Monterrey. Monterrey: Fondo Editorial Nuevo León, 2009.

Reguillo, Rossana. Paisajes insurrectos. Jóvenes, redes y revueltas en el otoño civilizatorio. Barcelona: Nuevos Emprendimientos Editoriales, S. L., 2017.

Ricoeur, Paul. La metáfora viva. Madrid: Ediciones Europa, 1980. Rivas, Eva, César Morado Macías, Mario Cerutti, y Octavio Herrera. "La historia en el noreste y desde el noreste". En Las ciencias sociales en el noreste de México, editado por César Morado Macías y Lucila Hinojosa. Ciudad de México: Universidad Autónoma de Nuevo León - Facultad de Filosofía y Letras, 2016.

Sillares, vol. 1, núm. 2, 2022

DOI: https://doi.org/10.29105/sillares1.2-1 
Roel, Santiago. Nuevo León, apuntes históricos. Monterrey: Ediciones Castillo, 1977.

Saldaña, José Pedro. Grandeza de Monterrey y estampas antiguas de la ciudad. México, DF: Empresas Editoriales S.A., 1973.

Saragoza, Alex. La elite regiomontana y el Estado mexicano, 1880-1940. Monterrey: Fondo Editorial Nuevo León, 2008.

Segato, Rita Laura. "Identidades políticas y alteridades históricas: una crítica a las certezas del pluralismo global”. Nueva Sociedad, núm. 178 (2002): 104-25.

Sheridan Prieto, Cecilia. Fronterización del espacio hacia el norte de la Nueva España. México, DF: Centro de Investigaciones y Estudios Superiores en Antropología Social; Instituto Mora, 2015.

Smith Pussetto, Cintia, Nancy Janett García Vázquez, y Jesús David Pérez Esparza. "Análisis de la ideología empresarial regiomontana. Un acercamiento a partir del periódico El Norte". CONfines de Relaciones Internacionales y Ciencia Política 4, núm. 7 (2008): 11-25.

Snodgrass, Michael. Deferencia y desafio en Monterrey. Trabajadores, paternalismo y revolución en México, 1890-1950. Monterrey: Fondo Editorial Nuevo León, 2008.

Tamez Solís, Porfirio. "Presentación". En El Nuevo Reyno de León. Un Estado sin impuestos, editado por Abelardo Leal. Monterrey: Universidad Autónoma de Nuevo León, 1982.

Tamez Solís, Porfirio. "Presentación”. En Amparo 71/933: Abelardo A. Leal vs. La ley de la abogacía, editado por Abelardo Leal. Monterrey: Universidad Autónoma de Nuevo León, 1985.

Sillares, vol. 1, núm. 2, 2022 
Valenzuela Arce, José Manuel. "Interculturalidad y estados nacionales". En Pensar las ciencias sociales hoy. Reflexiones desde la cultura, editado por Rossana Reguillo y Raúl Fuentes Navarro, 119-42. Guadalajara: Instituto Tecnológico y de Estudios Superiores de Occidente, 1999.

Vázquez, Josefina Zoraida. "La supuesta República del Río Grande". En Décadas de inestabilidad y amenazas. Antología de ensayos, editado por Josefina Zoraida Vázquez, 61-88. El Colegio de México, 2010.

Vellinga, Menno. Desigualdad, poder y cambio social en Monterrey. México, DF: Siglo XXI, 1988.

Villasana Dávial, J. "Regionalismo político en México en el período 2000-2007: ¿un fenómeno que resurge?" Universidad del País Vasco, 2011.

\section{Hemerográficas}

Periódico El Norte.

Periódico El Porvenir.

Periódico Milenio Monterrey.

Periódico Milenio. 